\title{
MALT lymphoma in terminal ileum a case report
}

\author{
Yeti Indrawati
}

\author{
Siloam Hospital Manado \\ Email: yeti_indrawati1@yahoo.com
}

\begin{abstract}
Abstrak: Mucosa associated lymphoid tissue lymphoma (MALToma) merupakan subtipe ketiga tersering dari limfoma non-Hodgkin. Gejala klinis sering insidius sebagai lesi yang low grade dan cenderung terlokalisasi untuk waktu lama. Saluran cerna, terutama lambung, merupakan lokasi ekstranodal tersering. MALToma dari ileum jarang ditemukan dengan patogenesis yang tidak diketahui pasti. Mengenai 5-year survival untuk MALToma dilaporkan 81\%. Kami melaporkan kasus seorang laki-laki berusia 80 tahun dirawat di Bagian Emergensi RS Siloam Manado dengan nyeri abdomen dan adanya massa dalam abdomen. Pemeriksaan radiologi abdomen dan USG memperlihatkan adanya massa pada area usus halus. Pada pasien ini dilakukan laparotomi. Hasil histopatologik menunjukkan suatu MALT limfoma dari ileum terminalis.
\end{abstract}

Kata kunci: MALT limfoma, ileum terminalis.

\begin{abstract}
Mucosa associated lymphoid tissue lymphoma (MALToma) is the third most common non-Hodgkin's lymphoma subtype. Clinical presentation is often insidious as a low grade lesion and the disease tends to remain localized for a long period of time. The gastrointestinal tract, but in particular the stomach, is by far the most common extra-nodal site. MALToma of ileum, however is rare. Little is known with certainty about the pathogenesis of the disease but overall 5-year survival for MALToma is reported as $81 \%$. We reported an $80-$ year-old male presented to the Emergency Department of Siloam Hospital Manado with abdominal pain and an abdominal mass. He underwent an abdominal radiology and abdominal ultrasound which showed a mass in the small intestinal area. A laparotomy and a tumor biopsy were performed on him. The histopathological result was consistent with MALT lymphoma of terminal ileum.
\end{abstract}

Keywords: MALT lymphoma, terminal ileum

Approximately $8 \%$ of all non-Hodgkin lymphomas are extra-nodal marginal zone B cell lymphoma of mucosa associated lymphoid tissue (MALT), also known as MALT lymphoma, which was first described in 1983 by Isaacson and Wright. $^{1,2}$ They discovered that primary low-grade gastric B cell lymphoma and immunoproliferative small intestinal disease had more histological features in common with those of MALT than with peripheral lymph nodes. ${ }^{3}$ Extranodal lowgrade lymphoma arising at other mucosal organs, including the salivary gland, lung, and thyroid, showed similar histological and clinical features, ${ }^{4}$ establishing the term MALT lymphoma. These MALT lymphomas arise at a wide range of different extranodal sites, including the stomach (70\%), lung (14\%), ocular adnexa (12\%), thyroid (4\%), and small intestine including immunoproliferative small intestinal disease $(1 \%) .^{5}$ MALT lymphoma of the ileum, however, is rare.

Lymphoma is defined as a neoplastic proliferation of lymphoid cell. About $90 \%$ 
of all lymphoid malignancies are of B-cell lineage, whilst a minority are of $\mathrm{T}$-cell $(7 \%)$ or NK-cell lineage $(<2 \%)$. In 1832 Thomas Hodgkin first described what became known as Hodgkin lymphoma. Hodgkin lymphoma (HL) accounts for approximately $30 \%$ of all lymphomas. Approximately $70 \%$ of lymphoma do not have the clinical and pathological features of HL and have therefore been categorized historically as non-Hodgkin lymphoma (NHL). NHL is frequently disseminated and all considered malignant or potentially malignant. Some aggressive from the outset, while others are indolent for varying lengths of time, but may transform to more aggressive tumors. The most common type of NHL is diffuse large B-cell lymphoma which represents $29 \%$ of all NHL and characterized by clonal expansion of neoplastic follicle centre-type cells. The third most frequent subtype of B-cell NHL is chronic lymphocytic leukemia/small lymphocytic lymphoma (12\%), followed closely by extranodal marginal zone lymphoma of MALT (MALT lymphoma) which accounts for $9 \%$ of all B-cell lymphoma. Both MALT and follicular lymphoma may transform to a high grade lymphoma, most frequently diffuse large B-cell lymphoma. ${ }^{6}$

MALT lymphoma or MALToma is an indolent neoplasma where tumours tend to stay localized at their site of origin until the late phase of the disease. It occurs at various extra-nodal sites. The most common site is the gastrointestinal (GI) tract, comprising $50 \%$ of all cases, and within the GI tract, the stomach is the most common location accounting for $85 \%$ of GI MALToma. The small intestine is typically involved in patient with immuneproliferative small intestinal disease (IPSI). Other frequent sites include salivary gland, lung, ocular adnexa, skin, thyroid and breast. $^{5}$ Apart from the small intestine, these anatomical sites are normally devoid of organized lymphoid tissue, thus MALToma appears to arise from acquired MALT, commonly due to chronic immunelogical stimulation, resulting either from pathogen infection or autoimmune disorders. ${ }^{7}$ Patients are generally present with MALToma at stage I or II. The average age of disease onset is 61 years and the 5-year survival rate of patients has been as high as $93 \%$ in some studies. The median time before progression of the disease is approximately 5 years although it is significantly longer for case with gastrointestinal origin compared to those from other sites. ${ }^{8}$ About $2-20 \%$ of patients have bone marrow involvement and up to $10 \%$ have lymphoma in multiple extranodal sites, ${ }^{9}$ but they generally respond well to therapy and have good overall prognosis. ${ }^{10}$

\section{Pathogenesis}

The etiology of esophageal MALToma remains unclear; it may be a result of exposure to food additives, hot liquids. or mechanical stimulation. ${ }^{11}$ Unlike the stomach, an association with Helicobacter pylori has yet been reported. ${ }^{12}$ In the gastric mucosa, chronic inflammation- as with an infection such as $H$. pylori, inflammatory or autoimmune states can precipitate organization of lymphoid tissue; ${ }^{1}$ from this, MALToma is derived. ${ }^{13} H$. pylori contribute to approximately $90-95 \%$ of cases of gastric MALToma. ${ }^{14}$ Rarely, other infections, such as Helicobacter heilmannii, may cause gastritis, ${ }^{15}$ predisposing to MALToma, too. ${ }^{16}$ Possible explanations for the presence of MALToma in the absence of $H$. pylori include: technical issues resulting in the failure to identify the presence of $H$. pylori (e.g. biopsies from incorrect location or failure to recognize microorganisms on histological preparations); sampling after initiation of antibiotic therapy; advanced disease obscuring evidence of previous infection; an infectious etiology other than of infection (e.g. autoimmune); or other mechanism of tumorigenesis (e.g. genetic, or environmental). ${ }^{17}$

In the intestine, MALToma may arise from the normal lymphoid components (Figure 1). Alternatively, it may be derived from acquired lymphoid tissue. Unlike the 
stomach, an association with an infectious agent, such $H$. pylori, has not been described in small bowel MALT lymphoma (Figure 2). ${ }^{17}$

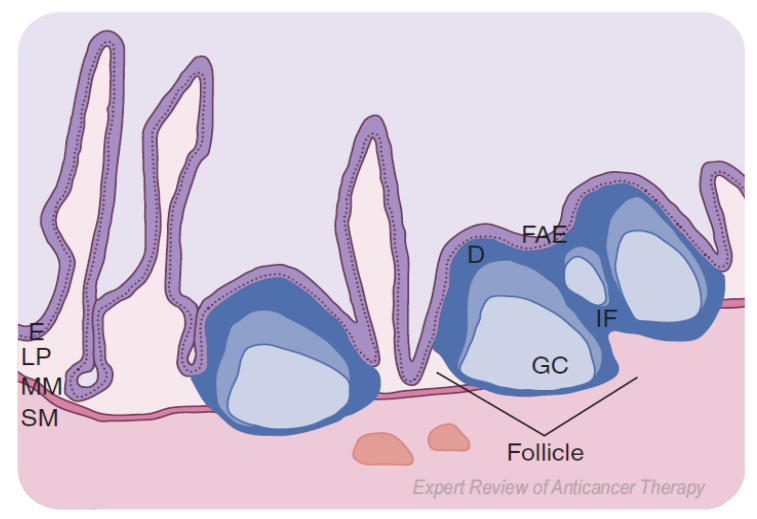

Figure 1. Normal small intestine mucosa containing a Peyer's patch. The mucosa contains E, LP, and MM; below this is the SM. The Peyer's patch consists of lymphoid aggregates that contain four distinct regions: the D, FAE, IF, and follicle; the follicle contains a GC. D: Dome; E: Epithelium; FAE: Follicle-associated epithelium; GC: Germinal center; IF: Interfollicular region; LP: Lamina propria; MM: Muscularis mucosa; SM: Submucosa. 5

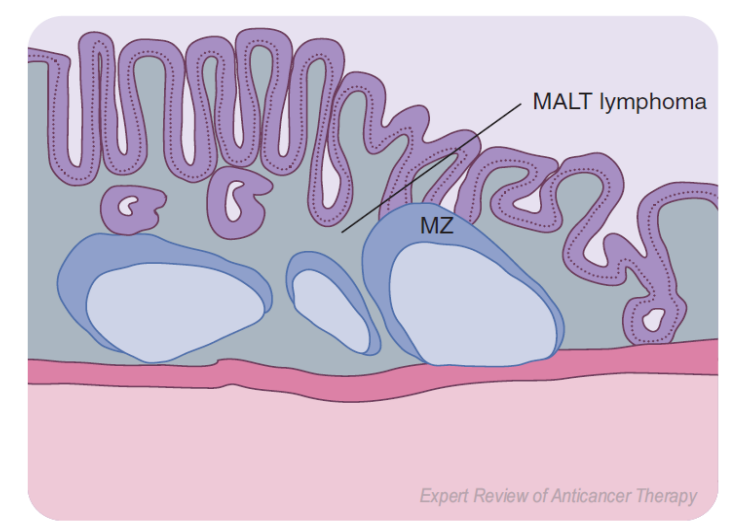

Figure 2. MALT lymphoma. The neoplastic cells (dark gray) diffusely surround the lymphoid follicles and extend throughout the mucosa. The MZ of the reactive follicles remains intact. MALT: Mucosal-associated lymphoid tissue; MZ: Mantle zone. ${ }^{5}$

In the colon, the cause also remains unknown, but an infectious etiology has been proposed. ${ }^{18}$ Primary small and large intestinal MALTomas are characterized by a strong association with aneuplody, primarily in the form of trisomy 3 and/or 18 ; rarely $\mathrm{t}(11 ; 18)(\mathrm{q} 21 ; \mathrm{q} 21)$ or $\mathrm{t}(1 ; 14)(\mathrm{p} 22 ; \mathrm{q} 32)$ may occur. ${ }^{19}$ Indeed, the former observation may broadly implicate the putative locations of genes contributing to the development of this neoplasm, a different pathogenesis compared with that of gastric MALT, and serve as a means of differentiating primary from secondary MALTomas involving the intestine. ${ }^{19}$ Therefore, the presence of characteristic translocations of gastric MALT lymphoma in the intestine raises the possibility of a secondary spread, which occurs with a relatively high frequency. ${ }^{19}$

The histological feature of MALToma comprises infiltration of marginal zone spreading diffusely into the surrounding tissue. MALT lymphoma bears a striking resemblance to normal MALT and Peyer's patches (PPs). ${ }^{20}$ Architecturally, PPs can be divided into four zones: FAE, dome, follicle and the interfollicular region (Figure 3). Focally, the tall columnar epithelial cells are interrupted by patches of lympho-epithelium containing fewer goblet cells and containing a specialized cuboidal epithelium punctuated by microfold (M) cells. The latter is an epithelial cell that samples macromolecules, antigens and microorganisms from the intestinal lumen, presenting them to the underlying immune cells; indeed, the $M$ cells are thought to play a key role in intestinal immunity. Aggregates of $\mathrm{B}$ and $\mathrm{T}$ cells are found in the FAE; compared with the adjacent villous epithelium, there is a predominance of CD4+ T cells. Separating the FAE from the follicle is the dome region, which contains a mixed inflammatory component, including B cells, plasma cells, dendritic cells, and macrophages. The germinal center of the follicle contains macrophages, CD4+ $\mathrm{T}$ cells and a predominance of immunoglobulin (Ig)A+ B cells; this is surrounded by the mantle zone, primarily comprised of $\operatorname{IgD}$ and $\operatorname{IgM}+{ }^{21}$

MALToma cells share the same cytological and immunophenotypical 
(CD20+, CD21+, CD35+, IgM+, and IgD-) features as marginal zone $B$ cells prompting the World Health Organization to designate this lymphoma as extranodal marginal zone B cell lymphoma of mucosa associated lymphoid tissue (MALT lymphoma). ${ }^{21}$ The lymphoma cells often resemble follicle-centre centrocytes, small lymphocytes, or the so-called monocytoid B cells. Another important histological feature of it is the presence of lymphoepithelial lesions formed by the lymphoma cell invasion of individual mucosa glands or other epithelial structures. Transformed blast and plasma cells are scattered, present beneath the surface epithelium, possibly indicating that the MALT lymphoma might participate in the immune response. The lymphoma cells also enter the germinal centers of nonneoplastic B cell follicles- a process known as follicular colonization. ${ }^{22}$

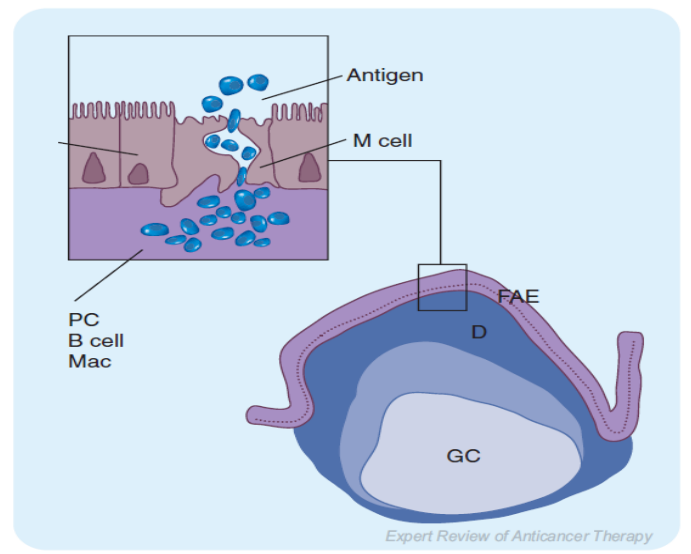

Figure 3. Peyer's patch, illustrating $M$ cells. A lymphoid follicle containing a GC is seen within a Peyer's patch. M cells are scattered among ECs at the lumen surface and transport antigen into the underlying extracellular domain. In the D region below the FAE, there is a mixed population of immune cells including PCs, Mac and B cells that sample and respond to these antigens. D: Dome; EC: Epithelial cell; FAE: Follicle-associated epithelium; GC: Germinal center; Mac: Macrophages; M: Microfold; PC: Plasma cells. ${ }^{5}$

\section{Clinical features}

MALToma is rarely observed in the esophagus, with fewer than ten reports in the literature. Patients are typically over 55 years of age and there is a male predominance; they may be asympto-matic or complain of dyspepsia. ${ }^{11}$

MALToma is more commonly found in the stomach. ${ }^{23}$ Patient tend to be over 50 years of age; there are slightly differing reports on whether there is male. ${ }^{12}$ or slight female, ${ }^{24}$ predominance. Patient may be asymptomatic or complain of halitosis, dyspepsia, early satiety, weight loss, nausea or vomiting. In the small intestine, MALToma comprises two main entities, Western-type MALToma and immuneproliferative small intestine disease (IPSID). The former is predominance and displays similar features to that gastric MALToma. ${ }^{25}$

In the small intestine, MALTomas tend to occur in older patients and are slightly more common in males. ${ }^{25}$ Symptoms are generally nonspecific and characterized by vague abdominal pain and weight loss. Rarely, patients may present with evidence of obstruction or perforation. Intestinal MALToma appears to have a worse prognosis than that of stomach. ${ }^{26}$ It worsens with evidence of transformation into highgrade diffuse large B-cell lymphoma (DLBCL) ${ }^{27}$ In the small intestine, DLBCL is more common than MALToma.

MALToma is rare in the large intestine; however, this represents a major proportion of large bowel lymphomas. ${ }^{28}$ Some cases are secondary in origin, thus, necessitating rigorous evaluation. Common symptoms include abdominal pain and hematochezia; perforation may rarely occur. $^{29}$

\section{Treatment}

Adequate staging- in the form of imaging studies, endoscopic ultrasound and biopsy sampling- is essential for directing treatment decisions and predicting the potential response to treatment. This is true for both gastric and extragastric MALToma. ${ }^{30} \mathrm{~A}$ recent prospective study demonstrated $25 \%$ of gastric and $46 \%$ of 
extragastric MALToma exhibited multiorgan involvement upon rigorous staging. ${ }^{31}$ This confirms differing patterns of spread and a greater tendency for dissemination by extragastric MALToma. Presently, treatment of gastric MALT lymphoma entails triple therapy with a proton pump inhibitor, clarithromycin, and either amoxicillin or metronidazole. ${ }^{32}$ Treatment success can be confirmed with follow-up biopsy after 1 or 2 months. $^{33}$ This regimen produces regression of low-grade MALToma in approximately $75 \%$ of cases $;{ }^{34}$ generally, this occurs within 1 year, but it may take longer. $^{35}$ Failure to eradicate $H$. pylori necessitates an additional course of treatment. Failure of MALToma to regress within 1 year may be interpreted as treatment failure. Some suggested that this was an indication for chemotherapy or radiation treatment. ${ }^{23}$ Others have demonstrated that patients harboring minimal recidual disease can be managed by using watch-and-wait strategy. ${ }^{35}$ As recidual MALToma may also impart an increased risk of gastric carcinoma, long term endoscopic follow up with careful sampling would be indicated in these circumstances. ${ }^{36}$

A randomized trial comparing the efficacy of chemotherapy (cyclophosphamide-doxorubicin-vincristine followed by cyclophosphamide-vincristine-prednison), radiation, and surgery in the treatment of early stage (IE and IIE) gastric MALToma failed to reveal a statistical difference in overall survival between treatment groups, with a complete response rate of $100 \%$ in each treatment axis; actuarial curves showed chemotherapy was associated with an improved event-free survival. ${ }^{37}$ Low dose radiotherapy has also been independently verified as highly effective in the treatment of gastric MALTomas. ${ }^{38}$ Until recently, surgical resection represented a keystone in the management of gastric MALToma. ${ }^{39}$ A prospective study evaluating the efficacy of surgery recently confirmed the utility of surgery, particularly in the case of early gastric lymphoma. It also highlighted the potential limitation associated with an inadequate biopsy technique, confirming the need for optimizing endoscopic sampling strategies. ${ }^{39}$

However, given the success of noninvasive treatments, current algorithms for the treatment of gastric MALT lymphoma do not contain a pivotal role for surgery. ${ }^{40}$ Therefore, surgery should reserved for those patients that are not candidates for chemotherapy, ${ }^{37}$ instances involving disease-related complications and select cases of persistent aggressive disease. ${ }^{40}$ There are anecdotal reports of management of MALT in areas such as thyroid, salivary glands and rectum with regiments targeting $H$. pylori. ${ }^{18}$ Currently, there is no well-established association between primary MALT lymphoma in esophagus, small bowel or colon with an infection such as $H$. pylori; therefore, the use of antibiotics in the treatment of such extragastric MALToma is not substantiated. While further research is required in this regard, there is recent evidence discounting a role for antibiotic therapy in the treatment of extranodal MALToma. ${ }^{41}$ Endoscopic mucosal resection with. ${ }^{12}$ or without adjuvant radiation are both possible therapeutic options for esophageal MALToma. Similarly, there are no clear guidelines for the management of MALToma in the small bowel. At present, a case by case evaluation may take into consideration a combination of surgery, radiation, chemotherapy, or immunetherapy. ${ }^{42}$ Treatment in colon MALToma is variable and depends on the disease burden. Local disease may be managed in some cases with surgical or endoscopic resection. ${ }^{39}$ Locally advanced and systemic disease requires broader chemotherapeutic consideration. $^{43}$

\section{CASE REPORT}

We reported a case of an 80-year-old male admitted to the Emergency Department of Siloam Hospital Manado with a 3-month history of intermittent right lower abdominal pain, and an abdominal mass, followed by anorexia and weight 
loss. There was no history of other diseases or medicamental administration.

During physical examination the patient looked alert. Vital signs showed heart rate of $80 / \mathrm{min}$; respiratory rate of $20 / \mathrm{min}$; blood pressure of $110 / 70 \mathrm{mmHg}$, and oxygen saturation of $98 \%$, and afebrile Heart sounds were normal without murmurs. Lung auscultation was uneventful. In abdominal examination, there was a palpable mass in the right lower quadrant abdomen. Extremities were normal without edema.

The laboratory investigation showed hemoglobin of 9,8 $\mathrm{g} / \mathrm{dl}$, and normal levels of glucose as well as the liver function tests. Lymphocyte count was $11.9 \%$ (low), albumin 3,2 g/dl, natrium $134 \mathrm{mmol} / \mathrm{l}$, and creatinin 1,62 $\mathrm{mg} / \mathrm{dl}$. The CEA serology test of CEA was 2,41ng/dl (normal) and of CA $19-9$ was $3,5 \mathrm{U} / \mathrm{ml}$ (normal). Chest X ray showed normal result. Abdominal ultrasound showed a mass in the intestinal area.

The patient was handled with a laparotomy. During surgery, a tumor infiltrating to the abdominal fascia wall in terminal ileum was detected. There was an enlargement mesenterical lymphoid glands; therefore right hemicolectomy was performed.

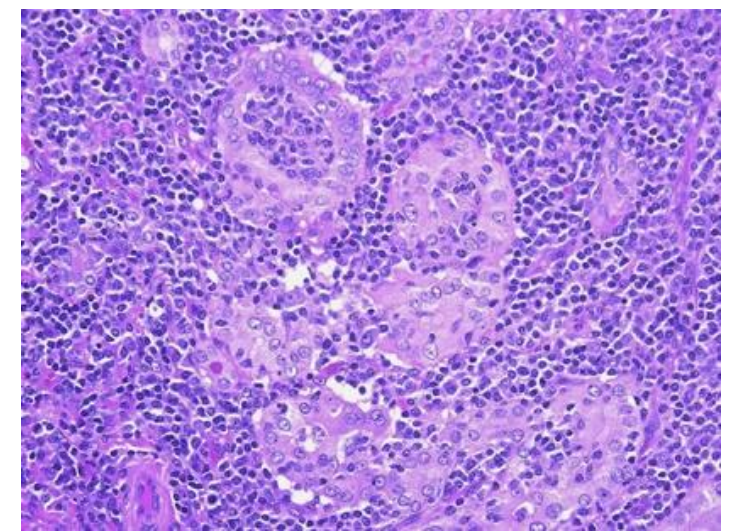

Figure 4. Round hyperchromatic nucleus cells that were diffuse and monotonous, penetrating the muscular layer to serous layer between the fat tissue.

A biopsy was performed. Macroscopically, there was a piece of tissue sized
$17 \times 11 \times 9 \mathrm{~cm}^{3}$ and a tumour of $6 \times 5 \times 3 \mathrm{~cm}^{3}$. The microscopic examination revealed round hyperchromatic nucleus cells that were diffuse and monotonous, penetrating the muscular layer to serous layer between the fat tissue (Figure 4). The final diagnosis was MALT lymphoma of terminal ileum.

\section{DISCUSSION}

A case report is presented in which a 80-year-old male with abdominal pain and abdominal mass, followed by anorexia and weight loss, with a diagnosis of mucosa associated lymphoid tissue lymphoma (MALToma), obtained based on biopsy result.

This case was a male of 80 years old with a 3-month history of intermittent right lower abdominal pain, and an abdominal mass, followed by anorexia and weight loss. This is similar with the literature statement that the small intestine MALTomas tend to occur in older patients, are slightly more common in males, with generally nonspecific symptoms characterized by vague abdominal pain and weight loss. $^{25}$

In this case, it could be difficult to distinguish whether the location of tumor was colon or small intestine. The combination of abdominal radiology, abdominal ultrasound, laparoscopy, and histopathological examination were the cornerstone of confirming the diagnosis of this rare MALT lymphoma of terminal ileum.

As for the other MALTomas, there are no clear guidelines for the management of MALToma in the small intestine. Other cases of colon lymphoma are treated as the same which is surgery first and followed by chemotherapy. ${ }^{13,43}$ At present, a case by case evaluation may take into consideration a combination of surgery, radiation, chemotherapy or immunotherapy. ${ }^{42}$ This patient was planned for a chemotherapy in the next schedule control.

\section{CONCLUSION}

MALT lymphoma of terminal ileum is 
a rare condition. Since MALT lymphoma of terminal ileum is not easy to differentiate from others tumors of this site clinically and radiologically, endoscopic biopsy and accurate histopathological diagnosis are essential diagnostic tools to plan an optimal treatment strategy. The clinical outcome may be excellent if the diagnosis is confirmed earlier, even when presenting with rare clinical manifestations.

\section{REFERENCES}

1. Campo E, Chott A, Kinney MC, Leoncini L, Meijer CJ, Papadimitriou CS, et al. Update on extranodal lymphomas. Conclusions of the workshop held by the EAHP and the SH in Thessaloniki, Greece. Histopathology. 2006;48(5): 481-504.

2. The non-Hodgkin's lymphoma classification Project. A clinical evaluation of the International Lymphoma Study Group classification of non-Hodgkin's lymphoma. Blood. 1997;89(11):390918.

3. Isaacson $\mathbf{P}$, Wright DH. Malignant lymphoma of mucosa-associated lymphoid tissue. A distinctive type of B-cell lymphoma. Cancer. 1983;52(8):1410-6.

4. Addis BJ, Hyjek E, Isaacson PG. Primary pulmonary lymphoma: a re-appraisal of its histogenesis and its relationship to pseudolymphoma and lymphoid interstitial pneumonia. Histopathology. 1988;13(1):1-17.

5. Isaacson PG, Du MQ. MALT lymphoma: from morphology to molecules. Nature Reviews Cancer. 2004; 4(8):644-53.

6. Swerdlow SH, Campo E, Harris NL, Jaffe ES, Pileri SA, Stein H, et al. WHO Classification of tumours of haematopoeitic and lymphoid tissues (4th ed), 2008; p. 1-439.

7. Du MQ. MALT lymphoma: recent advances in aetiology and molecular genetics. $\mathbf{J}$ Clin Exp Hematop. 2007;47: 31-42.

8. Thieblemont C, Bastion Y, Berger F, Rieux C, Salles G, Dumontet C, et al. Mucosa-associated lymphoid tissue gastrointestinal and nongastrointestinal lymphoma behavior: analysis of 108 patients. J Clin Oncol. 1997;15:162430.
9. Isaacson PG, Spencer J. Malignant lymphoma of mucosa-associated lymphoid tissue. Histopathology. 1987;11: 445-62.

10. Fischbach W, Goebeler ME, RuskoneFourmestraux A, Wundisch T, Neubauer A, Raderer M, et al. Most patients with minimal histological residuals of gastric MALT lymphoma after successful eradication of Helicobacter pylori can be managed safely by a watch and wait strategy: experience from a large international series. Gut. 2007;56:1685-7.

11. Hosaka S, Nakamura N, Akamatsu T, Fujisawa T, OgiwaraY, Kiyosawa K, et al. A case of primary low grade mucosa associated lymphoid tissue (MALT) lymphoma of the oesofagus. Gut. 2002;51 (2):281-4.

12. Kitamoto $\mathbf{Y}$, Hasegawa $\mathbf{M}$, Ishikawa $\mathbf{H}$ Saito J, Yamakawa M, Kojima M, et al. Mucosa-associated lymphoid tissue lymphoma of the esophagus: a case report. J Clin Gastroenterol. 2003;36(5):414-6.

13. Isaacson PG. Update on MALT lymphomas. Best Pract Res Clin Haematol. 2005;18(1):57-68.

14. Ye H, Liu H, Raderer M, Chott A, Ruskone-Fourmestraux A, Wotherspoon A, et al. High incidence of $\mathrm{t}(11 ; 18)(\mathrm{q} 21 ; \mathrm{q} 21)$ in Helicobacter pylori-negative gastric MALT lymphoma. Blood. 2003;101(7): 254750.

15. Jhala D, Jhala N, Lechago J, Haber M. Helicobacter heilmannii gastritis: association with acid peptic diseases and comparison with Helicobacter pylori gastritis. Mod Pathol. 1999;12(5):534-8.

16. Morgner A, Lehn N, Andersen LP, Thiede C, Bennedsen M, Trebesius $K$, et al. Helicobacter heilmannii-associated primary gastric low-grade MALT lymphoma: complete remission after curing the infection. Gastroenterology. 2000;118(5):821-8.

17. Gascoyne RD, Muller- Hermelink HK, Chott A, Wotherspoon A. B-cell lymphoma of the small intestine. In: Hamilton SR, Aaltonen LA, editors. Pathology and Genetics: Tumours of the Digestive System. Lyon: IARC 
Press, 2000; p. 83-6.

18. Nakase H, Okazaki K, Ohana M, Ikeda K, Uchida $\mathbf{K}$, Uose $\mathbf{S}$, et al.The possible involvement of microorganisms other than Helicobacter pylori in the development of rectal MALT lymphoma in $\mathrm{H}$. pylori-negative patients. Endoscopy. 2002;34(4):3436.

19. Streubel B, Seitz G, Stolte M, Birner P, Chott A, Raderer M. MALT lymphoma associated genetic aberrations occur at different frequencies in primary and secondary intestinal MALT lymphomas. Gut. 2005;55(11):1581-5.

20. Isaacson PG, Wright DH. Extranodal malignant lymphoma arising from mucosa-associated lymphoid tissue. Cancer. 1984;53(11):2515-24.

21. Isaacson PG. WHO Classification of Tumours: Pathology and Genetics Tumours of Haematopoietic and Lymphoid Tissues. Geneva: WHO, 2001.

22. Isaacson PG, Wotherspoon AC, Diss T, Pan LX. Follicular colonization in Bcell lymphoma of mucosa-associated lymphoid tissue. American Journal of Surgical Pathology. 1991;15(9):81928.

23. Du MQ, Atherton JC. Molecular subtyping of gastric MALT lymphomas: implications for prognosis and management. Gut. 2006;55(6):886-93.

24. Shirsat H, Vaiphei K. Primary gastrointestinal lymphomas - A study of 81 cases from a tertiary healthcare centre. India $\mathbf{J}$ of Cancer. 2014;51(3):290-2

25. Miyazaki T, Kato $\mathbf{H}$, Masuda $\mathbf{N}$, Nakajima M, Manda R, Fukuchi M, et al. Mucosa-associated lymphoid tissue lymphoma of the esophagus: case report and review of the literature. Hepato-gastroenterology. 2004;51(57):750-3.

26. Isaacson PG. Gastrointestinl lymphoma of T- and B cell types. Mod Pathol. 1999;12 (2):151-8.

27. Isaacson PG. Primary gastric lymphoma. Pathol Oncol Res. 1996;2(1-2):5-10.

28. Muller-Hermelink HK, Chott A, Gascoyne RD, Wotherspoon A. Bcell lymphoma of the colon and rectum. In : Hamilton SR, Aaltonen L, editors. Pathology and Genetics: Tumours of the Digestive System. Lyon: IARC Press, 2000; p. 139-41.

29. Wotherspoon A, Chott A, Gascoyne RD, Muller-Hermelink HK. Lymphoma of the oesofagus. In: Hamilton SR, Aaltonen LA, editors. Pathologic and Genetic Tumours of the Digestive system. Lyon: IARC Press, 2000; p. 27.

30. Fischbach W, Goebeler-Kolve ME, Greiner A. Diagnostic accuracy of EUS in the local staging of primary gastric lymphoma: results of a prospective, multicenter study comparing EUS with histopathologic stage. Gastrointest Endosc. 2002;56(5):696-700.

31. Raderer M, Vorbeck F, Formanek M, Osterreicher C, Valencak J, Penz M, et al. Importance of extensive staging in patients with mucosa-associated lymphoid tissue (MALT)-type lymphoma. $\mathrm{Br} \quad \mathrm{J}$ Cancer. 2000;83(4):454-7.

32. Ford A, Moayyedi P. How can the current strategies for Helicobacter pylori eradication therapy be improved? Can J Gastroenterol. 2003;17(Suppl B):B36-B40.

33. Yamashita H, Watanabe $\mathbf{H}$, Ajioka Y, Nishikura K, Maruta K, Fujino MA. When can complete regression of lowgrade gastric lymphoma of mucosaassociated lymphoid tissue be predicted after Helicobacter pylori eradication. Histopathology. 2000;37(2):131-40.

34. Morgner A, Bayerdorffer E, Neubauer A, Stolte M. Gastric MALT lymphoma and its relationship to Helicobacter pylori infection: management and pathogenesis of the disease. Microsc Res Tech. 2000;48(6):349-56.

35. Fischbach W, Goebeler-Kolve M, Starostik P, Greiner A, MullerHermelink HK. Minimal residual low-grade gastric MALT-type lymphoma after eradication of Helicobacter pylori. Lancet. 2002; 360(9332):547-8.

36. Copie-Bergman C, Locher C, Levy M, Chaumette MT, Haioun C, DelfauLarue MH, et al. Metachronous 
gastric MALT lymphoma and early gastric cancer: is residual lymphoma a risk factor for the development of gastric carcinoma? Ann. Oncol. 2005;16(8):1232-6.

37. Aviles A, Nambo MJ, Neri N, Talavera A, Cleto S. Mucosa-associated lymphoid tissue (MALT) lymphoma of the stomach: results of a controlled clinical trial. Med Oncol. 2005;22(1):57-62.

38. Schechter NR, Portlock CS, Yahalom J. Treatment of mucosa-associated lymphoid tissue lymphoma of the stomach with radiation alone. J Clin Oncol. 1998;16(5): 1916-21.

39. Fischbach W, Dragosics B, KolveGoebeler ME, Ohmann C, Greiner A, Yang Q, et al. Primary gastric Bcell lymphoma: results of a prospective multicenter study. The GermanAustrian Gastrointestinal Lymphoma Study Group. Gastroenterology. 2000;119(5):1191-202.
40. Yoon SS, Coit DG, Portlock CS, Karpeh MS. The diminishing role of surgery in the treatment of gastric lymphoma. Ann Surg. 2004;240(1):28-37.

41. Grunberger B, Wohrer S, Streubel B, Formanek M, Petkov V, Puespoek A, et al. Antibiotic treatment is not effective in patients infected with Helicobacter pylori suffering from extragastric MALT lymphoma. J Clin Oncol. 2006;24(9):1370-5.

42. Bertoni F, Zucca E. State-of-the-art therapeutics: marginal-zone lymphoma. J Clin Oncol. 2005;23(26):6415-20.

43. McLaughlin P, Hagemeister FB, Romaguera JE, Sarris AH, Pate O, Younes A, et al. Fludarabine, mitoxantrone, and dexamethasone: an effective new regimen for indolent lymphoma. J Clin Oncol. 1996;14(4):1262-8. 